\title{
Atrio-Ventricular Septal Defect in Pregnant Women, How to Deal with It : A Case Study
}

\author{
Devie Caroline ${ }^{1, *}$, Moh. Yogiarto ${ }^{2}$ \\ ${ }^{1}$ Mitra Keluarga Kenjeran Hospital Surabaya, Indonesia, ${ }^{2}$ Department of Cardiology and Vascular Medicine \\ Faculty of Medicine, Airlangga University/Soetomo General Hospital Surabaya, Indonesia
}

${ }^{*}$ Corresponding author:

Devie Caroline, MD, -email :devcarol2017@gmail.com

Cardiologist at Mitra Keluarga Kenjeran Hospital Surabaya, East Java, Indonesia

Manuscript submitted: October 28, 2017; Revised and accepted: January 5, 2018

\begin{abstract}
Pregnancy is not always well tolerated in women with congenital heart disease (CHD) such as atrio-ventricular septal defect (AVSD), predominantly due to heart failure deterioration and increasing pulmonary hypertension $(\mathrm{PH})$. Managements of those patients are challenging, especially during third trimester and after delivery care. Decision about time of termination, mode of delivery and anesthetic management are also debatable. In this article we report two similar cases of pregnant women with AVSD and severe PH. The first patient was 27 years old, 28-29 weeks pregnant came with shortness of breath. She had history of miscarriage once. Based on her transthoracal echocardiography, she was diagnosed with AVSD partial type (primum ASD) with severe PH and then treated with intravenous furosemide, oral beraprost and oral sildenafil. The second patient was 27 years old 30-31 weeks pregnant with shortness of breath and appeared cyanotic. She delivered her first child spontaneously without any symptoms. Based on her transthoracal echocardiography she was diagnosed with AVSD transitional type (large primum ASD with small inlet VSD) and Eisenmenger syndrome. She was treated with intravenous furosemide and oral beraprost. Those two patients underwent planned C-section under general anesthesia, both babies were survived but the patient did not survived several days after the procedure due to $\mathrm{PH}$ crisis. Until now, management $\mathrm{PH}$ associated with $\mathrm{CHD}$ in pregnant women is complex. Fluid management and pulmonary artery hypertension (PAH)targeted therapies are important. Mode of delivery on this cases is also remain debated. Some studies stated planned C-section might be a better choice and combination epidural and lowdose spinal anesthesia might be better than general anesthesia. At the end, when a woman with $\mathrm{CHD}$ and $\mathrm{PH}$ chooses to continue pregnancy, multidisciplinary team approach is crucial to achieve good outcomes.
\end{abstract}

Keywords: AVSD; pregnancy; pulmonal hypertension; Eisenmenger

\section{INTISARI}

Kehamilan tidak selalu dapat diterima dengan baik pada wanita dengan penyakit jantung bawaan (PJB) seperti defek septum atrio-ventikular (AVSD), terutama karena bertambah beratnya gejala gagal jantung dan hipertensi pulmonal $(\mathrm{PH})$. Penatalaksanaan pasien tersebut sangat sulit, terutama pada trimester ketiga dan setelah persalinan. Kapan waktu yang tepat untuk terminasi kehamilan, metode persalinan dan manajemen anestesi juga masih dalam perdebatan. Pada artikel ini dilaporkan dua kasus wanita hamil dengan AVSD dan PH berat. Pasien pertama seorang wanita 27 tahun, hamil 28-29 minggu, datang dengan keluhan sesak napas. Pasien mempunyai riwaya abortus spontan sekali. Berdasarkan ekhokardiografi transthorakal, pasien didiagnosis dengan AVSD tipe parsial (primum ASD) dengan PH berat dan kemudian diterapi dengan furosemide intravena, beraprost dan sildenafil oral. Pasien kedua adalah wanita 27 tahun hamil 30-31 minggu dengan keluhan sesak napas dan tampak sianosis. Pasien melahirkan anak pertama secara spontan tanpa gejala apapun. Berdasarkan ekhokardiografi transthorakal, 
pasien didiagnosis dengan AVSD tipe transisional (ASD primum besar dengan VSD inlet kecil ) dan sindroma Eisenmenger. Pasien diterapi furosemide intravena dan beraprost oral. Kedua pasien tersebut kemudian dilakukan Sectio Caesarean (SC) secara elektif dengan anestesi umum, kedua bayi lahir selamat namun kedua pasien tersebut meninggal beberapa hari pasca tindakan dengan penyebab krisis hipertensi pulmonal. Sampai saat ini, manajemen PH akibat penyakit jantung bawaan (PJB) pada ibu hamil sangat kompleks dan sulit. Manajemen cairan dan terapi hipertensi pulmonal menjadi penting. Metode persalinan kasus semacam ini juga masih dalam perdebatan Beberapa penelitian menyatakan bahwa SC elektif mungkin menjadi pilihan. Pilihan metode anestesi seperti kombinasi epidural dan anestesi spinal dosis rendah dikatakan lebih baik daripada anestesi umum. Pada akhirnya ketika seorang wanita dengan PJB dan $\mathrm{PH}$ memilih untuk melanjutkan kehamilan, pendekatan multidisiplin sangatlah penting untuk mencapai hasil yang baik.

\section{INTRODUCTION}

Atrio-Ventricular Septal Defect (AVSD) occurs due to fusion failure of the embryonic endocardial chusion in primitive AV channels. The characteristic of AVSD is deficient atrioventricular (AV) septation and a variety of AV valve anomalies. ${ }^{1}$ The prevalence is only $4-5 \%$ of all congenital heart defects. Most AVSD patients can reach adulthood without marked clinical symptoms, and sometimes get pregnant and is able to deliver the baby spontaneously without any symptoms ${ }^{2}$. Pregnancy in women with AVSD is not always well tolerated to these patients, as there may be worsening of heart failure and an increasing of regurgitation of the $A V$ valve. In addition, AVSD patients who become pregnant usually have pulmonary hypertension $(\mathrm{PH})$ where according to $\mathrm{WHO}$ women with $\mathrm{PH}$ are class IV (pregnancy is contraindicated). If pregnancy occurs then termination should be considered. Until now, there are no standardized management of pregnant women with pulmonary hypertension. There should be multidisciplinary care by cardiologists, obstetricians, and anesthesiologists as well as neonatologists to reduce mortality.

\section{CASE REPORT}

Case I

A woman, 27 years old was referred to Cardiology outpatient clinic, she was diagnosed with suspected mitral stenosis from the previous hospital. She felt shortness of breath since the last 2 weeks and had to sit while sleeping at night. Patient had history of heart disease since she was 10 years old but rarely went to the doctor to get medication. She had history of spontaneous abortion once, at that time the second pregnancy was 28-29 weeks gestation. On physical examination, blood pressure was $105 / 73 \mathrm{mmHg}$, heart rate was 90 beat/ min regular, respiratory rate was $28 \mathrm{time} / \mathrm{min}$, and oxygen saturation was $96 \%$ breathing room air. She looked pale with no cyanosis. On cardiac auscultation there were systolic murmur in intercostal space II left parasternal line grade III / VI, systolic murmur in intercostal space IV left parasternal line and holosystolic murmur in the apex grade IV I VI radiates to axilla. On the lungs we found bibasilar fine rales. There was pitting edema on her feet. The abnormal laboratory result was only mild anemia (haemoglobin $11 \mathrm{~g} / \mathrm{dL}$ ) with mild hipoalbuminemia (albumin $3.2 \mathrm{~g} / \mathrm{dL}$ ). From the chest $\mathrm{X}$-ray, there was cardiomegaly with prominent pulmonary cone and increased pulmonary vascularity (Figure 1). From the transthoracal echocardiography (TTE): there was mitral cleft with severe mitral regurgitation (RV $83 \mathrm{ml}$ ), severe tricuspid regurgitation (maxPG 84 $\mathrm{mmHg}$ ), and moderate pulmonic regurgitation. There was intra atrial septal defect $3.6 \mathrm{~cm}$ left to right shunt without anterior rim (Figure 2). We assessed the patient with primum atrial septal 
defect (ASD) left-to-right shunt with severe $\mathrm{PH}$ and decompensated heart failure NYHA functional class III. We decided to hospitalize the patient until the fetus was viable (33-34 weeks of gestation) and gave her oxygenation, intravenous furosemide b.i.d, oral beraprost $20 \mathrm{mcg}$ t.i.d and oral sildenafil $50 \mathrm{mg}$ o.d. We performed TTE evaluation after pulmonary artery hypertension (PAH) targeted therapy, the $\mathrm{PH}$ decreased from severe into moderate. At 34 weeks of gestation, she underwent sectio caesarean (SC) under general anesthesia (GA). The baby was born with Apgar score 3-5 then 7-8, weight $1900 \mathrm{~g}$. After the procedure we put the patient on oral beraprost $40 \mathrm{mcg}$ t.i.d, oral sildenafil $50 \mathrm{mg}$ o.d

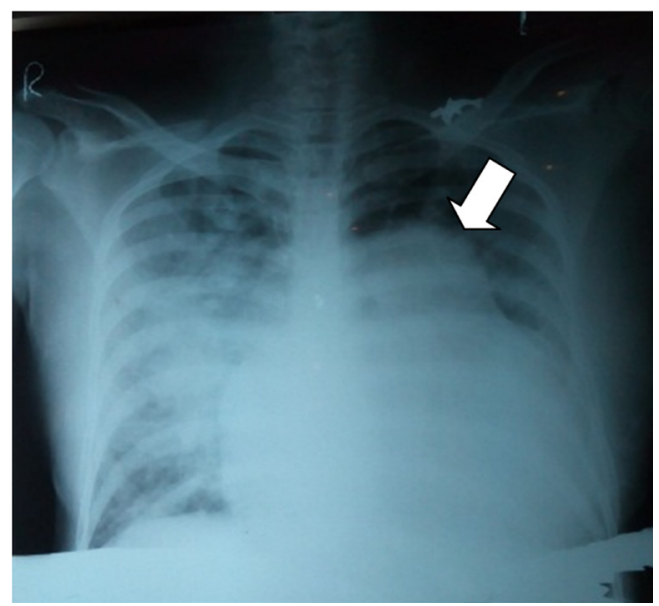

Figure 1. Chest X-ray showed enlargement of the heart with CTR $70 \%$. Prominent pulmonary cone (white arrow) with increasing pulmonary vascularity. CTR : Cardio Thoracic Ratio. and intravenous ceftriaxone $1 \mathrm{~g}$ b.i.d. But the patient's condition was deteriorated, she got fever, the shortness of breath was worsened and blood pressure fell to $60 / 40 \mathrm{mmHg}$. We gave norepinephrin and dopamin support. She was reintubated but she did not survived day 5 after SC. The patient passed away probably due to $\mathrm{PH}$ crisis which lead to cardiogenic shock and complicated with septic shock.

Case II.

A woman, 27-year-old, was consulted from Obstetry and Gynecology Division with 30-31 weeks pregnancy and shortness of breath with blueish on tip of her fingers. The patient got shortness of breath since the last 2 months, her feet got swollen and she noted that her fingertips became blueish in the last 1 month. The patient had never complained any medical symptoms before and gave birth to the first child spontaneously without any symptoms. From the physical examination blood pressure was 100/48 $\mathrm{mmHg}$, heart rate was 95 beat/ min, respiratory rate was 32 time/ min and oxygen saturation was $82 \%$ breathing room air. She appeared cyanotic and dyspneic. From cardiac auscultation there were systolic murmur in intercostal space IV left parasternal line and holosystolic murmur in the apex radiates to the axilla. No rales on lung auscultation, there was leg edema, cyanosis and clubbing fingers. Laboratory results were unremarkable, and chest X-ray showed
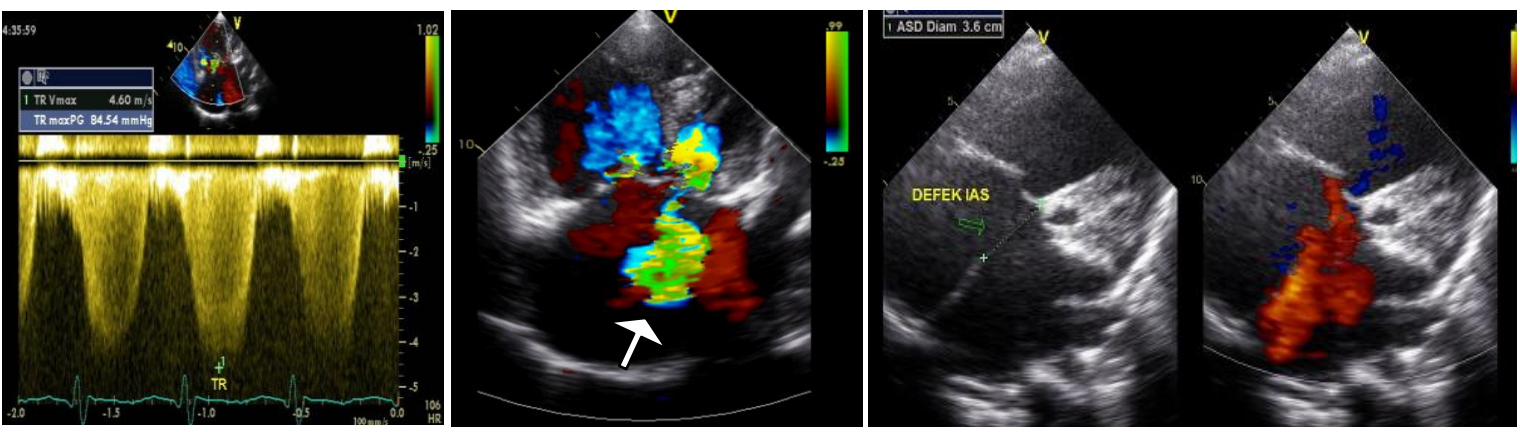

Figure 2. Colour doppler shows severe TR (max PG 84,5 mmHg). Color doppler shows severe MR (white arrow) and ASD $3.6 \mathrm{~cm}$ left-to-right shunt. TR : tricuspid regurgitation, MR : mitral regurgitation, ASD : atrial septal defect, PG: pressure gradient. 
cardiomegaly with prominent pulmonary cone (Figure 3).

From TTE we found cleft mitral with severe mitral regurgitation (RV $50 \mathrm{ml}$ ), severe tricuspid regurgitation (maxPG $135.6 \mathrm{mmHg}$ ) with moderate pulmonal regurgitation. Right ventricle systolic function was decreased (TAPSE $1.5 \mathrm{~cm}$ ). There was large intra ASD $6.2 \mathrm{~cm}$ bidirectional shunt right to left shunt dominantly and also small inlet VSD $(0.3 \mathrm{~cm})$. The estimation pulmonary arterial systolic pressure (PASP) was $145 \mathrm{mmHg}$. (Figure 4)

We assessed the patient with AVSD transitional type (large primum ASD with small inlet VSD) and Eisenmenger Syndrome. We gave her oxygenation with simple mask,

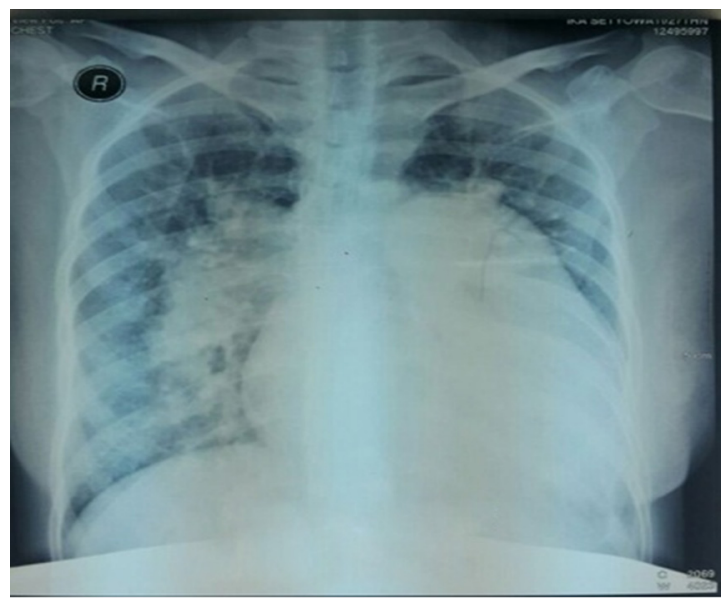

Figure 3. Cardiomegaly with prominent pulmonary cone and hillus. intravenous furosemide b.i.d and oral beraprost 20 mcg t.i.d. The patient was then performed an evaluation of $\mathrm{PH} 2$ days after therapy, the PASP was decreased but still in severe $\mathrm{PH}$. Then the patient underwent SC procedure under GA, the baby born weighing $1000 \mathrm{~g}$, Apgar score 3-5. However, during intensive care management, the condition was deteriorating. The oxygen saturation was decreased and blood pressure fell to $70 / 40 \mathrm{mmHg}$ which not respond with norepinephrin and finally the patient passed away on the second day after SC due to pulmonary hypertension crisis.

\section{DISCUSSION}

These two patients were in stable condition before pregnancy, moreover the second patient was able to deliver her baby spontaneously without serious complications. While not in pregnancy these two patients should had been in condition similar to those of secundum type ASD, in which the right atrium (RA) and right ventricle (RV) are dilated with increased pulmonary blood flow. The cleft mitral valve is usually insignificant from a hemodynamic point of view because blood regurgitated into the left atrium (LA) is immediately shunted to the RA, thereby decompressing the LA. The symptoms are shortness of breath, and easily fatigue. ${ }^{5,6}$ But during pregnancy, the hemodynamic is different.
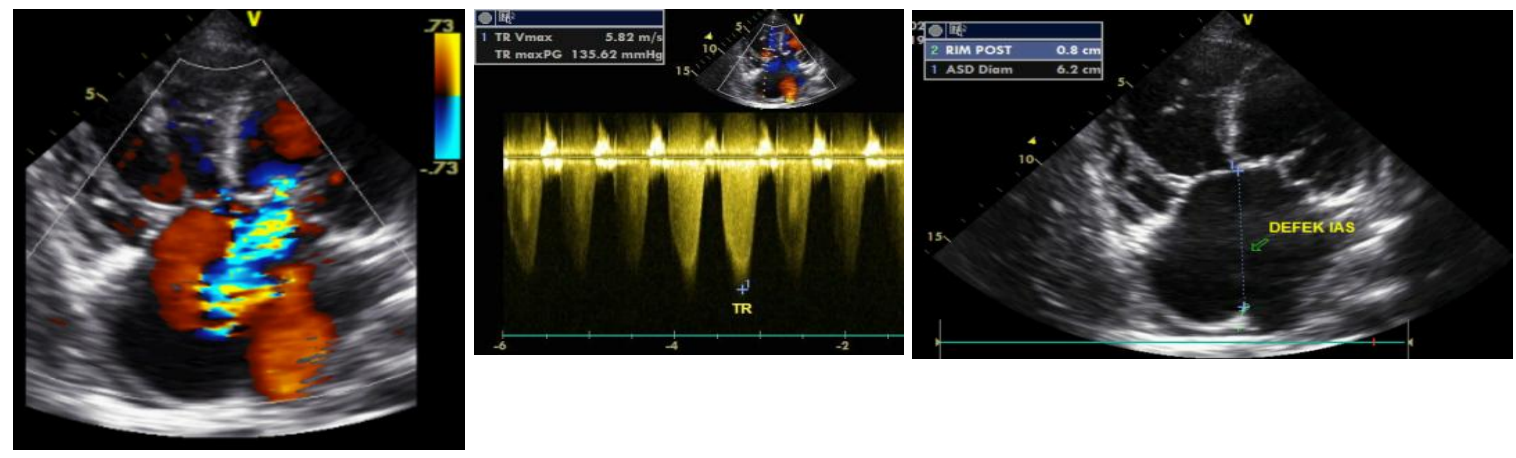

Figure 4. Colour doppler showss Severe MR (white arrow). Colour doppler measurement of severe TR (maxPG $135 \mathrm{mmHg}$ ) and large IAS defect $6.2 \mathrm{~cm}$. TR : tricuspid regurgitation, MR : mitral regurgitation, IAS : inter atrial septum, PG: pressure gradient.. 
Moreover AVSD patients who become pregnant usually have pulmonary hypertension.

Pregnancy is associated with increased plasma volume and decreased systemic vascular resistance, both resulting in an increase in cardiac output. In healthy women a decrease in pulmonary vascular resistance accommodates the requirements for increased cardiac output. In women with pulmonary hypertension, pulmonary vascular disease prevents the fall in pulmonary vascular resistance, leading to a rise in pulmonary artery pressure with increased cardiac output. Ultimately, the necessary increase in cardiac output cannot be achieved resulting in right heart failure. ${ }^{3,7}$ Then these two pregnant patients were treated with bed rest, oxygenation, intravenous diuretic for volume overload and pulmonary vasodilators or $\mathrm{PAH}$ targeted therapy. The choice for PAH targeted therapy for these patients was beraprost (prostacyclin analog), its effect is vasodilatation on pulmonary vasculature. Even though the safety of beraprost during pregnancy was unknown or has not been established (and should not be used in pregnant woman), we decided to give the patient beraprost because of its availability, and also economic issue of it. We also gave the first patient sildenafil (PDE5 inhibitor). Sildenafil causes vasodilation of the pulmonary vascular bed and in the systemic circulation. It also has a positive inotropic effect on the hypertrophic right ventricle with category $B$ medication (safe for pregnancy). Using sildenafil to treat $\mathrm{PH}$ in pregnancy has been described in case reports and appears to be safe, but experience is still limited. We did not have endothelin receptor antagonist (ERA) such as bosentan or illoprost at that time. Moreover Bosentan was are pregnancy category $X$ drugs and contraindicated in pregnancy. ${ }^{3}$

After the careful management, those two patient underwent $\mathrm{PH}$ evaluation using TTE. The first patient was able to reach moderate $\mathrm{PH}$ (from severe $\mathrm{PH}$ ), but the second patient was not able to achieve moderate $\mathrm{PH}$ (she was already in Eisenmenger state). After having discussion with Obstetrician and Anesthesiologist then the decision for mode of termination was elective SC under general anesthesia. Recommendation for mode of delivery depends on the individual's condition and is still debatable. Vaginal delivery increases cardiac output and blood pressure especially during contractions (34\% of CO will increase after cervical dilatation). This is a problem in mothers with pulmonary hypertension because unable to increase the cardiac output. Elective SC is preferred over emergency. The type of anesthesia also become another problems. General anesthesia drug administration has unfavorable effects such as cardiodepressive (by volatile agents) and increased pulmonary vascular resistance (PVR) during intubation and positive pressure ventilation. Some studies recommend combination epidural anesthesia and low-dose spinal anesthesia to avoid vasodilatation. $3.7,8$

In this case, few days after the SC procedure both of the patient's condition were deteriorated. The blood pressure fell below $80 / 50 \mathrm{mmHg}$ and were not respond to vassopressor and inotropic. This condition was probably due to $\mathrm{PH}$ crisis which lead to low cardiac output and cardiogenic shock. Finally these two patients passed away during intensive care management post delivery care. This condition appropriate with most studies. They show maternal deaths in patients with pulmonary hypertension occur in the third trimester and the first months after delivery. Most of it is due to $\mathrm{PH}$ crisis, pulmonary thrombosis and refractory right heart failure. Risk factors for the occurrence of maternal death including late hospitalization, severity of pulmonary hypertension, and general anesthesia. ${ }^{3}$

\section{CONCLUSION}

We report two difficult cases of AVSD and severe $\mathrm{PH}$ in pregnant women. Both of patients 
were treated carefully with oxygenation, fluid restriction and pulmonary vasodilators, but few days after the SC procedure they experienced pulmonary hypertension crisis and did not survived. Due to a high maternal mortality risk, women with severe pulmonary hypertension and Eisenmenger syndrome had to be given a good counseling before pregnancy. If pregnancy occurs then termination should be considered, however when termination is declined, pregnancy and delivery should be managed by multidisciplinary services to achieving successful outcomes in these difficult cases.

\section{REFERENCES}

1. Poterucha J.T., Maleszewski J.J., O'Leary P.W., Cetta F.. 2015. Atrioventricular septal defects in echocardiography in Pediatric and Adult Congenital Heart Disease Second edition. Eds: Eidem B.W, O'Leary P.W, Cetta F. Philadelphia : Wolters Kluwers. pp.218242

2. Drenthen W., Pieper P.G., Van der Tuuk K., Roos-Hesselink J.W., Voors A.A., Bianca Mostert B., et al. 2005. Cardiac complications relating to pregnancy and recurrence of disease in the offspring of women with atrioventricular septal defects. Eur Heart J, 26: 2581-2587.
3. Bassily-Marcus A., Yuan C., Oropello J., Manasia A., Kohli-Seth R., Benjamin E. 2012. Pulmonary hypertension in pregnancy: critical care management. Pulmonary Medicine, Article ID 709407.

4. Altin F.H., Yildiz O., Karacalilar M., Tosun O., Kocyigit O.I., Erek E. 2015. Atrioventricular septal defect and pulmonary stenosis diagnosed in a 49-year-old woman after 10 uneventful births. Tex Heart Inst J, 42:166168.

5. Park M.K. 2014. Left to right shunts in Park's Pediatric Cardiology for Practitionerr, sixth edition. Philadelphia : Elsevier-Saunders. pp. 277-319.

6. Rudolph A.M. 2009. Atrioventricular septal defects in Congenital Diseases of the Heart Clinical-Physiological Considerations 3rd edition. Hong-Kong: Blackwell Publishing. pp. 203-224.

7. Pieper P.G., Hoendermis E.S. 2011. Pregnancy in women with pulmonary hypertension. Neth Heart J, 19:504-508.

8. Regitz-Zagrosek V.R, Lundqvist C.B, Borghi C, Cifkova R, Ferreira R, Foidart JM, et al. 2011. ESC Guidelines on the management of cardiovascular diseases during pregnancy. Eur Heart J, 32: 3147-3197. 